\title{
Bedre oppfølging av premature
}

\author{
Foreldre med premature barn var tilfredse med tilbudet ved ressurshelsestasjonene i Bærum kommune.
}

a aglige retningslinjer for oppfølging av for tidlig fødte barn anbefaler at man tilbyr premature barn og deres familier en mer omfattende og målrettet oppfølging (1). Helsesøstre skal ha relevant kunnskap og tilby oppfølging som tar sikte på å lære foreldre å forstå barnets behov. Dette vil på sikt ha betydning for barnets generelle utvikling $(2,3,4)$.

\section{Savnet kompetanse}

Prosjektet «Trygghet som foreldre til premature barn» ble gjennomført av Rikshospitalets nyfødtseksjon i tiden 1.4.2001-31.3.2003 (5). Helsesøstertjenesten fra Bærum kommune deltok i planlegging og gjennomføring av prosjektet, som hadde som mål «gjennom informasjon og veiledning å styrke foreldrene, slik at de har tilstrekkelig med kunnskap og ferdigheter til å mestre den daglige omsorg av det premature barnet hjemme». Som en del av dette prosjektet ble det gjennomført en brukerundersøkelse blant foreldre fra Asker og Bærum med barn som hadde vært innlagt ved nyfødtseksjonen ved Rikshospitalet. Brukerundersøkelsen viste at foreldre ikke var tilfredse med helsestasjonens tilgjengelighet, erfaring og kompetanse på premature barn.

\section{Hovedbudskap}

Vi har undersøkt om ressurshelsestasjonene for premature barn og deres foreldre i Bærum kommune bidrar til å gi foreldre med premature barn en trygg overgang fra sykehus til hjem. Hjelper helsesøster på ressurshelsestasjonen dem til å bli trygge i foreldrerollen? Hva kan eventuelt forbedres?

\section{Søkeord}

Les mer og finn litteraturhenvisninger på våre nettsider. \ Helsestasjon | Barn | Familie | Nyfødt

\section{Ressurshelsestasjoner}

Ved å opprette ressurshelsestasjoner, ønsket kommunen å bedre kvaliteten på oppfølgingen av premature barn. Helsestasjonstilbudet skulle være mer tilgjengelig og ha personell med erfaring og oppdatert kunnskap på dette området (6). Helsesøstrene fikk anledning til å skaffe seg spisskompetanse ved å hospitere ved nyfødtseksjonen og ved fagdager en gang i halvåret. Man ønsket å sikre et godt samarbeid mellom nyfødtseksjonen ved Rikshospitalet og ressurshelsestasjonene i kommunen. Oppfølging av de premature barna skulle tilrettelegges etter individuelle behov, og informasjonen til foreldrene skulle formidles slik at de ble forsvarlig ivaretatt. Premature ble i denne sammenheng definert som barn født i uke 34 eller tidligere. Med utgangspunkt i nasjonale faglige retningslinjer for oppfølging av for tidlig fødte barn, har Helsekontoret i Bærum utarbeidet et eget fagprogram og en serviceerklæring for oppfølging på helsestasjonen (6).

\section{Evaluering}

Hensikten med evalueringen var å dokumentere i hvilken grad foreldre til premature barn var tilfredse med tilbudet og om møtet med ressurshelsestasjonen hadde bidratt til å gi dem en trygg overgang fra sykehus til hjem. I tillegg ønsket vi å få frem utfordringer og forbedringsområder. I denne artikkelen vil vi først presentere foreldrenes synspunkter på ressurshelsestasjonene, deretter diskutere hva som kan forbedres. Evalueringen ble foretatt i tidsrommet desember 2009 til mars 2010 (7). Spørreskjema ble sendt til 97 familier fra deres respektive ressurshelsestasjoner. Det går ikke fram om det ble besvart i fellesskap av begge foreldrene eller kun én av dem.

\section{Metode}

Evalueringen ble foretatt som et ledd i kommunens kvalitetsutviklingsarbeid. Gjennomføring og analyse ble gjort av en ekstern medarbeider som ikke var tilknyttet den aktuelle avdelingen og som ikke kjente informantenes identitet. Dette var en evalueringsstudie der både kvantitativ og kvalitativ metode ble brukt (8). Spørreskjema og intervjuguide ble utarbeidet av en gruppe helsesøstre i samarbeid med en forsker. Dataene som kom inn ble analysert på intervallskalanivå. «Helt enig» fikk verdien 1, mens «Helt uenig» fikk verdien 4.

\section{Utvalg}

I perioden 2003 til 2009 var det cirka 170 barn som ble født før 34. uke i Bærum kommune. Det var ikke alle familier som benyttet seg av ressurshelsestasjonene, og noen hadde flyttet ut av kommunen i perioden. Det ble sendt ut spørreskjema, samt en purring, til 97 hustander som benyttet seg av tilbudet fra 2003 til 2009. Til sammen besvarte 77 familier spørreskjemaet, noe som ga en svarprosent på 79 prosent. Sammen med purrebrevet ble det vedlagt en forespørsel om det var noen av foreldrene som ønsket å la seg intervjue som en del av evalueringen. De fire mødrene som meldte seg til dette, ble så intervjuet av forskeren. Vi antok at størrelsen på utvalget, svarprosenten og intervjuers avstand til respondenten ville ivareta undersøkelsens reliabilitet. Intervjuene som ble utført underbygger spørreskjemaenes validitet.

\section{Resultater}

Resultatene er delt inn i tre hovedkategorier i henhold til kategoriene i spørreskjemaet; 1) Informasjon og veiledning, 2) Helsesøsters kunnskap og ferdigheter, 3) Grad av tilfredshet med tilbudet. Både data fra spørreskjemaene og intervjuene blir presentert i tekst og tabellform.

1) Informasjon og veiledning. Før utskrivning fra sykehuset hadde 73 prosent av respondentene fătt informasjon om ressurshelsestasjonene. Omtrent halvparten av de spurte hadde fått besøk av ressurshelsesøster på sykehuset, som 


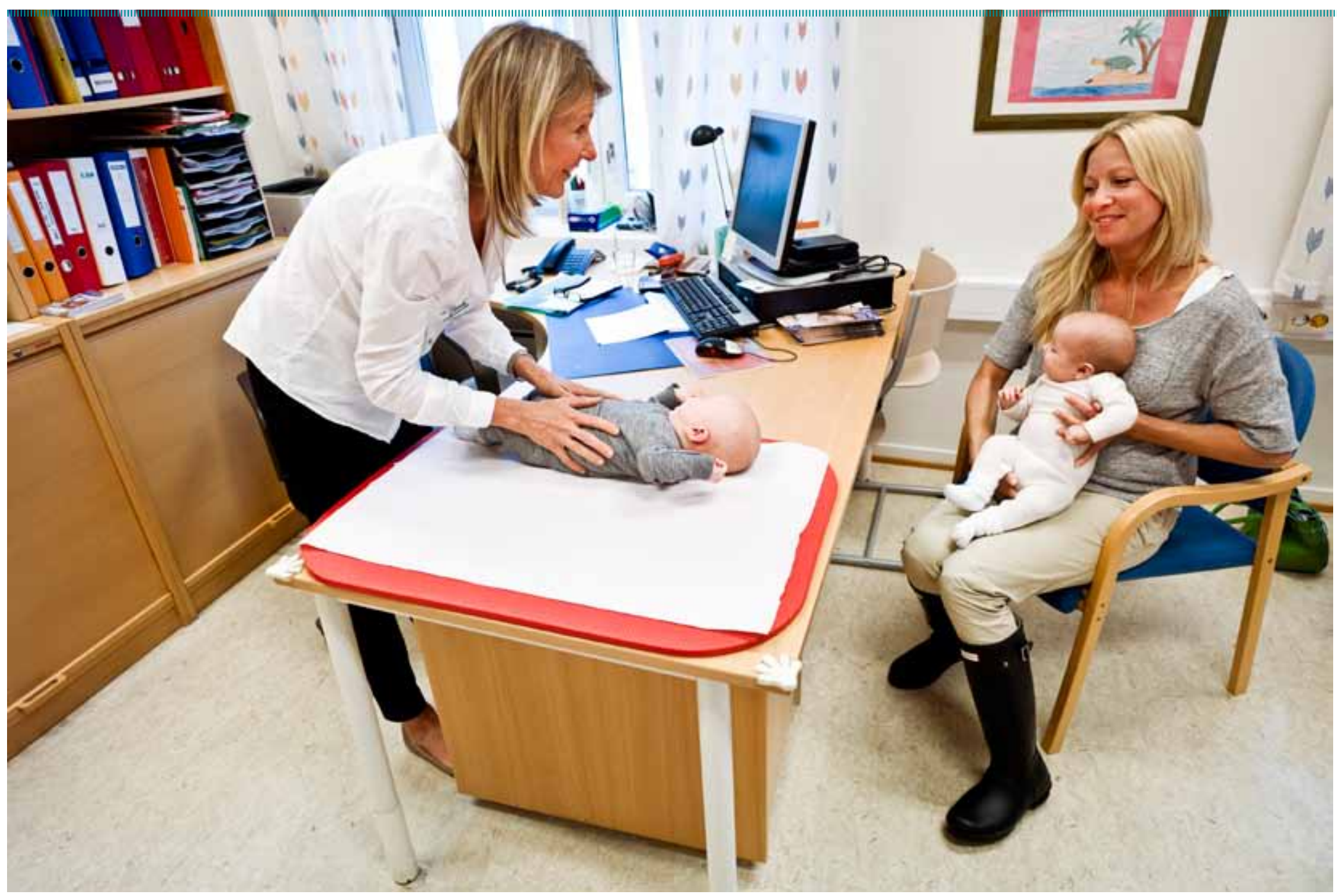

HAR OFTE KONTAKT: Helsesøster May Britt Farmen Holt har jevnlig møtt Tanja Skog og tvillingenen Mikkel og Ida siden de ble født i mai. Foto: Erik M. Sundt

formidlet informasjon om tilbudet og etablerte kontakt. Tilnærmet alle de spurte mente at helsesøster tok rask kontakt etter hjemkomst. Spørreskjemaene viste at familiene fikk informasjon om blant annet ernæring, spiseproblematikk, søvn, barnets utvikling, tolking av signaler, stimulering og skjerming, smittefare og infeksjoner. De fleste familiene mente at helsesøster hadde bidratt med lett forståelig og verdifull informasjon om det å ha ansvar for et prematurt barn, mens 9 prosent var helt uenige i at informasjonen var verdifull. Ved å slå sammen kategoriene «helt enig» og «litt enig» viste det seg at 87 prosent av foreldrene mente at ressurshelsestasjonenes tilbud hadde bidratt til en trygg overgang fra sykehus til hjem, og 85 prosent at helsesøster hadde vært en god støtte.

2) Helsesøsters kunnskap og ferdigheter. Mesteparten (82 prosent) av foreldrene var enige eller litt enige i at helsesøster hadde god kompetanse på premature barn, og at de følte seg trygge på at ressurshelsestasjonen ville oppdaget det hvis barnet ikke utviklet seg normalt. Tre av de fire mødrene som ble intervjuet opplevde at helsesøster hadde relevant kompetanse på premature barn. Det fremkom likevel fra intervjuene at flere ønsket helsesøster hadde mer kunnskap om flaskemating og ernæring og at det var behov for utvikling av kompetanse på dette området. En mor syntes ikke at helsesøster hadde relevant kompetanse på premature barn. På tross av varierende erfaring med «sin» helsesøster, oppgav den samme respondenten at hun var glad for at Bærum kommune har dette tilbudet til premature barn og deres foreldre.

3) Grad av tilfredshet med tilbudet. Nærmest alle som svarte på spørreskjemaene var enten helt enig eller litt enig $i$ at de hadde blitt godt ivaretatt på ressurshelsestasjonen. Den individuelle oppfølgingen besto av hyppig kontakt i form av hjembesøk eller konsultasjoner på helsestasjonen, og 84 prosent var helt eller litt enig i at møtet med ressurshelsestasjonen hadde gjort dem tryggere i foreldrerollen.

En mor uttalte: «Tryggheten er ikke så mye det medisinske, for det får du fra sykehuset, om det blir alvorlig så får du hjelp der, men det er mer sånt som ernæring, amming, alt som helsestasjonen driver med er enda viktigere for sånne små barn. Du får ikke svar i en bok, og bøker om premature barn er så skumle at dem burde man holde seg langt unna».

En annen mor fremhevet at møtet med ressurshelsesøster hadde gjort opplevelsen av krise lettere å håndtere: «Jeg hadde kjørt hvor som helst ellers for å få dette tilbudet. Jeg følte vi hadde vært gjennom en såpass spesiell situasjon at overgangen uten en sånn ressursperson hadde vært mye vanskeligere».

En mor opplevde at hun fikk lite støtte til egen psykiske helse: «(.....) jeg fikk et barn til, og da var det veldig mye fokus på mors psykiske helse, hvordan du føler deg, om du klarer å takle det, om du er litt deppa og sånn. Jeg fikk ikke det første gang».

\section{Nettverk viktig}

I tillegg var behovet for nettverk og støtte et område som ble utdypet $\mathrm{i}$ intervjuene. Tre av fire av mødrene som ble intervjuet hadde benyttet seg av tilbudet om barselgruppe der det kun var premature barn og deres mødre. Alle tre var fornøyde med gruppen som støtte og sosialt nettverk. I intervjuet uttaler en av mødrene: «(...) overgangen er helt umulig å fatte. Hvis man kanskje har fått sitt tredje barn og er veldig rolig av seg, så går det fint, men den situasjonen jeg opplevde på sykehuset var et sjokk ... det hadde ikke vært bra for meg eller barnet eller noen hvis man ikke hadde hatt et sikkerhetsnett».

En mor vektla barselgruppens nettverksfunksjon og støtte som viktig fordi de har andre typer spørsmål og bekymringer enn foreldre til terminbarn. En annen opplevde at gruppen ble satt 
i gang for sent: «Jeg har vært fornøyd med tilbudet, men for meg så skjedde det veldig sent. Fordi det er to barselgrupper i året og det betyr at det kan være seks måneders aldersforskjell og min sønn var blant de eldste. Han var født i september og vi begynte i mars, så jeg fikk ikke være med ... så det betydde at jeg var litt alene de første seks månedene».

\section{Diskusjon}

Et av hovedmålene med ressurshelsestasjonene er å bidra til en trygg overgang fra sykehus til hjemmet. Helsekontoret ønsker at foreldrene skal oppleve individuell tilrettelegging, at de får informasjon som er forståelig og at de blir ivaretatt og føler seg trygge. Ressurshelsestasjonene skal, ved å ha ny kunnskap og erfaring med premature barn, kunne tilby en mer individuelt tilpasset oppfølging.

\section{God støtte}

Resultatene viser at et overveiende flertall av foreldrene fikk informasjon om ressurshelsestasjonens tilbud mens de var innlagt på sykehuset, og at de opplevde informasjonen fra helsesøster som lett å forstå. Svarene viste at helsesøster vurderte hvilken informasjon foreldrene til enhver tid hadde behov for vedrørende for eksempel søvn, ernæring og trøst. Et overveiende flertall hadde opplevd støtten fra helsesøster som god.

På tross av de gode tilbakemeldingene fra mødrene som ble intervjuet, viser kommentarer og utsagn at noen områder kan forbedres. I det følgende vil vi diskutere disse områdene, som kan oppsummeres i følgende punkter:

- Oppdatering av kunnskap hos helsesøstre

- Oppfølging av mors psykiske helse

- Hyppigere oppstart av barselgruppe

\section{Helsesøsters kompetanse}

Å få et prematurt barn representerer en utfordring for de fleste foreldre. De viser blant annet tegn på overfølsomhet, forandret tidsoppfatning, søvnforstyrrelser og manglende appetitt, og har $ø$ kt risiko for stress, angst og depresjon (9). På nyfødtseksjonen har barnet vært under kontinuerlig overvåkning, og foreldrene har hatt fagfolk rundt seg hele døgnet. Det er en stor overgang å komme hjem og være alene med ansvaret. Det er derfor ekstra viktig med tett oppfølging den første tiden etter hjemreise $(10,11,12)$. Kvinner med psykiske tolkes som en indikasjon på at det kan foreligge forskjellige nivåer av kompetanse hos fagpersonell. Dette er interessant sett i forhold til en upublisert studie blant foreldre med premature barn, der man fant at bare halvparten av de spurte opplevde å bli møtt med god kompetanse om for tidlig fødte barn på helsestasjonen $(5,11)$.

\section{Mors psykiske helse}

De fire mødrene som ble intervjuet betegnet alle sammen perioden rundt fødselen og tiden etter som en krisesituasjon. Som tidligere beskrevet,

\section{«Det er en stor overgang å komme hjem og være alene med ansvaret.॥}

reaksjoner etter fødsel kan ha nedsatt sensitivitet for å respondere på barnets signaler. Dette vil kunne påvirke utviklingen av samspillet mellom mor og det premature barnet, noe som har stor betydning for barnets tidlige kognitive, språklige og sosioemosjonelle utvikling $(13,14)$.

Dette krever at helsesøster har nødvendig kompetanse på premature barn og kan gi tettere oppfølging enn av terminbarn $(9,15)$. Flertallet av de spurte mødrene nevnte i intervjuene at de syntes det var viktig at helsesøstrene var oppdatert på den nyeste forskningen på området. Veiledning gjør en stor forskjell når det gjelder å styrke foreldrenes trygghet og kompetanse og minske stress (2).

I gjennomgangen av kommentarene og $\mathrm{i}$ intervjuene fremkom det at flere respondenter opplevde at kompetansen varierte fra helsesøster til helsesøster. Om dette skyldtes tilfeldigheter eller om det er en reell forskjell er vanskelig å fastslå på bakgrunn av de data som foreligger. Funnene kan fremhevet en mor at opplevelsen av krise hadde vært lettere å håndtere med støtte av en ressursperson på helsestasjonen. Det samme opplever kvinner som får støttende oppfølgingssamtaler i forbindelse med barseldepresjoner (16). Tre av fire intervjuede mente de hadde opplevd at helsesøster var for lite oppmerksom på psykisk helse. De ga også uttrykk for at det var vanskelig å spørre om hjelp. De opplevde at det kunne være vanskelig å vedgå sine egne psykiske problemer når de egentlig burde vært glade for at det gikk bra med barnet. En mor beskrev det som uheldig at det ikke var mer oppmerksomhet rundt psykisk helse i en så vanskelig situasjon som det er å få et prematurt barn. Det er mulig at kvinnene fikk for liten oppmerksomhet i forhold til det premature barnet. Disse kvinnene burde få tilbud om å fylle ut kartleggingsskjemaet EPDS (Edinburgh Postnatale Depression Scale) ved første konsultasjon på helsestasjonen på lik linje med andre barselkvinner $(17,18,19)$.

\section{Usikker på hva pasienten sier?}

Ikke risiker liv og helse Bruk tolk

Se veileder om kommunikasjon via tolk, for mer informasjon om tolkebruk

www.helsedirektoratet.no
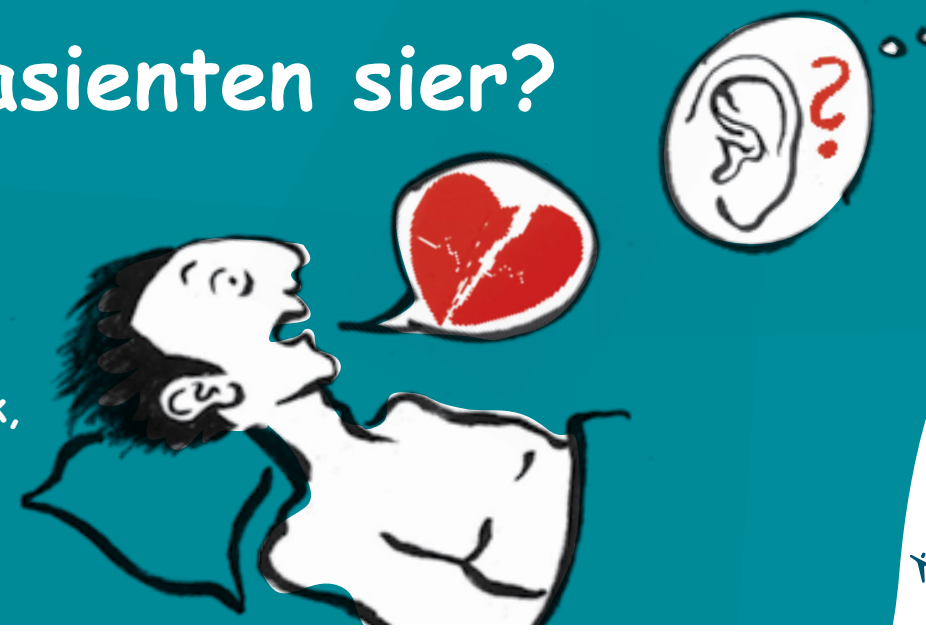

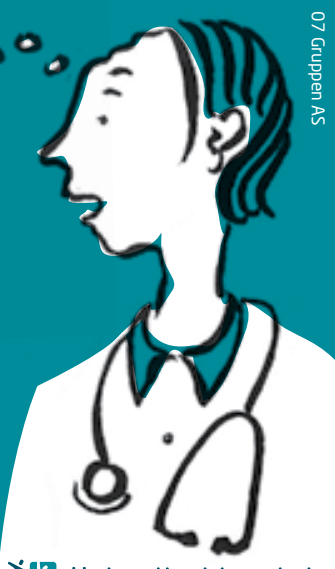

Helsedirektoratet 
En viktig støtte i spedbarnsperioden er den støtten foreldre kan gi hverandre (9). Kvinnene som ble intervjuet vektla betydningen av å kunne drøfte problemer og erfaringer med noen som hadde vært i samme situasjon. Det er derfor viktig å etablere barselgrupper hyppig, slik at alle får anledning til å delta så raskt som mulig etter hjemkomst.

\section{Konklusjon}

Resultatet av undersøkelsen viser at foreldrene i stor grad er fornøyde med ressurshelsestasjonenes tilbud og at et overveiende flertall mener ressurshelsestasjonene bidro til å gi dem en trygg overgang fra sykehus til hjem. Dette er i tråd med ressurshelsestasjonenes formål og viser således at man har lyktes med å skape et tilbud som gir god og individuell tilpasset oppfølging fra helsepersonell med god kompetanse på premature barn. På bakgrunn av uttalelser fra de intervjuede mødrene er det viktig at helsestasjonenes rutine med å kartlegge mors psykiske helse tilpasses foreldre med premature barn. Det er sannsynlig at barselgruppene har stor betydningen for mødrene. Det vil derfor være et positivt grep om flere fikk nytte av tilbudet på et tidligere tidspunkt i permisjonstiden og over lengre tid, uavhengig av fødselsdato.

\section{Oppsummering}

Evalueringen bekreftet at Helsekontorets satsing på ressurshelsestasjoner for premature barn var et riktig organisatorisk grep og inspirerer til en fortsatt satsing og utvikling av dette tilbudet. Evalueringen viste også til områder der det er behov for forbedringer. På bakgrunn av den kunnskap vi har om «late preterm infants» bør grensen for familier som får tilbud om oppfølging fra ressurshelsestasjonene heves til barn som er født før 37. uke $(20,21)$. For å imøtekomme kvinner med psykiske reaksjoner, bør man gjennomføre systematisk kartlegging ved hjelp av EPDS-skjemaet og oppfølgingssamtaler. I dag kartlegges alle mødre i kommunen for psykiske reaksjoner etter fødsel. Ut fra responsen både i intervjuene og i kommentarene i spørreskjemaet, vil Helsekontoret gi tilbud om hyppigere oppstart av barselgrupper. Utfordringen er å vedlikeholde samarbeidet med spesialisthelsetjenesten både når det gjelder oppfølging av familier og når det gjelder oppdatering av kunnskap for helsesøster og leger på ressurshelsestasjonene. For å unngå stor variasjon av kompetanse ved de forskjellige ressurshelsestasjonene, vil vi foreslå et tettere samarbeid mellom ressurshelsesøstrene, regelmessige møter, felles kurs og faglig oppdatering. På denne måten kan man sikre kunnskapsdeling på tvers av helsestasjonene.

Evalueringen ble støttet av prosjektmidler fra Helse- og rehabilitering gjennom Norske Kvinners Sanitetsforening. IIII
LITTERATUR

Sosial- og helsedirektoratet. Faglige retningslinjer for oppfølging av for tidlig fødte barn. 08/2007.

Kaaresen PI, Rønning JA, Ulvund SE, Dahl LB. A randomized, controlled trial of the effectiveness of an early intervention program in reducing parenting stress after preterm birth. Pediatrics 2006 July; 118(1): 9-19.

3. Olafsen KS. Precursors regulatory competence in term and preterm infants: The influence of a sensitizing intervention on temperament and social communication during the first year of life. Doktoravhandling. Universitetet i Troms $₫, 2010$.

4. Moss N, Hval M, Hellerud AK, Petersen NB. Samspillsveileder. Nyfødtintensiv. Sykehuset Buskerud. Helseregion Øst og Sør,2007.

Rikshospitalet. «Trygghet som foreldre til premature barn». Sluttrapport 2004.

5rumkommune Helsekontoret for barnogunge IS Servicerklering for Ressurshelsestasjoner for premature barni Bærum kommune». 2005.

7. Bærum kommune, Helsekontoret for barn og unge. Helsestasjonstilbudet til premature barn og deres foreldre. Evaluering. Bærum 2010

8. Kvale S. Interviews. An introduction to Qualitative Research Interviewing. Sage Publication, 1996.

9. Kloppen K. Hvordan kan helsevesenet støttemødre til premature barn det første året etter fødselen? Masteroppgave, Det Psykologiske Fakultet, Universitetet i Bergen, 2008.

10. Markestad T.Å være foreldre til et for tidlig født barn. Bergen: Fagbokforlaget, 2000

11. Karterud VL. Foreldre til premature barns behov for sykepleie ved overgangen fra nyfødtavdelingen til hjemmesituasjonen. Universitetet i Oslo, 2000.

12. Ravn IH. Klar for hjemreise? I: Tandberg BS, Steinnes S, red. Nyfødtsykepleie 2. Syke nyfødte og premature barn. Oslo:Cappelen Akademisk Forlag, 2009 SIDE 105-116.

13. Cho J, Holditch-Davis D, Miles MS. Effects of maternal depressive symptoms and infant gender on the interactions between mothers and their medically at-risk infants. J.Obstet.Gynecol.Neonatal Nurs 2008; 37:58-70.

14. Field T.Postpartum depression effects on early interactions, parenting, and safety practices: a review. Infant Behav.Dev 2010:33:1-6.

15. Olavsen ES, «Helsesøsterkompetanse og oppfølging av premature barn « MasTeris fakutet niversieteriosto 2010

16. Glavin K, Smith L, Sørum R, Ellefsen B. Supporting counselling by public health nurses for women with postpartum depression. Journal of advanced nursing. 2010 Jun:66(6): $1317-27$.

17. Glavin K. «Women with postpartum depression - an early identification and intervention study». Doktoravhandling. Oslo: Det medisinske fakultetet, Universitetet iOslo, 2010

18. Glavin K, Ellefsen B, Erdal B. Norwegian public health nurses'experiece using a screening protocol for postpartum depression. Public Health Nurse 2010; 27(3):255-62.

19. Bærum kommune, Psykisk helsetjeneste for barn og unge. uTilpasningsvansker og psykiske reaksjoner hos kvinner i forbindelse med svangerskap, fødsel og barseltid» Rapport, Bærum, 2007.

20. Altman M, Vanpee M, Bendito A, Norman M. Shorter hospital stay for moderately preterm infants. Acta Paediatrica 2006; 95: 1228-1233.

21. Engle WA, Tomashek KM. WallmanC. «Late-preterm» infants: a population at risk.Pediatrics 2007:120:1390-1401.

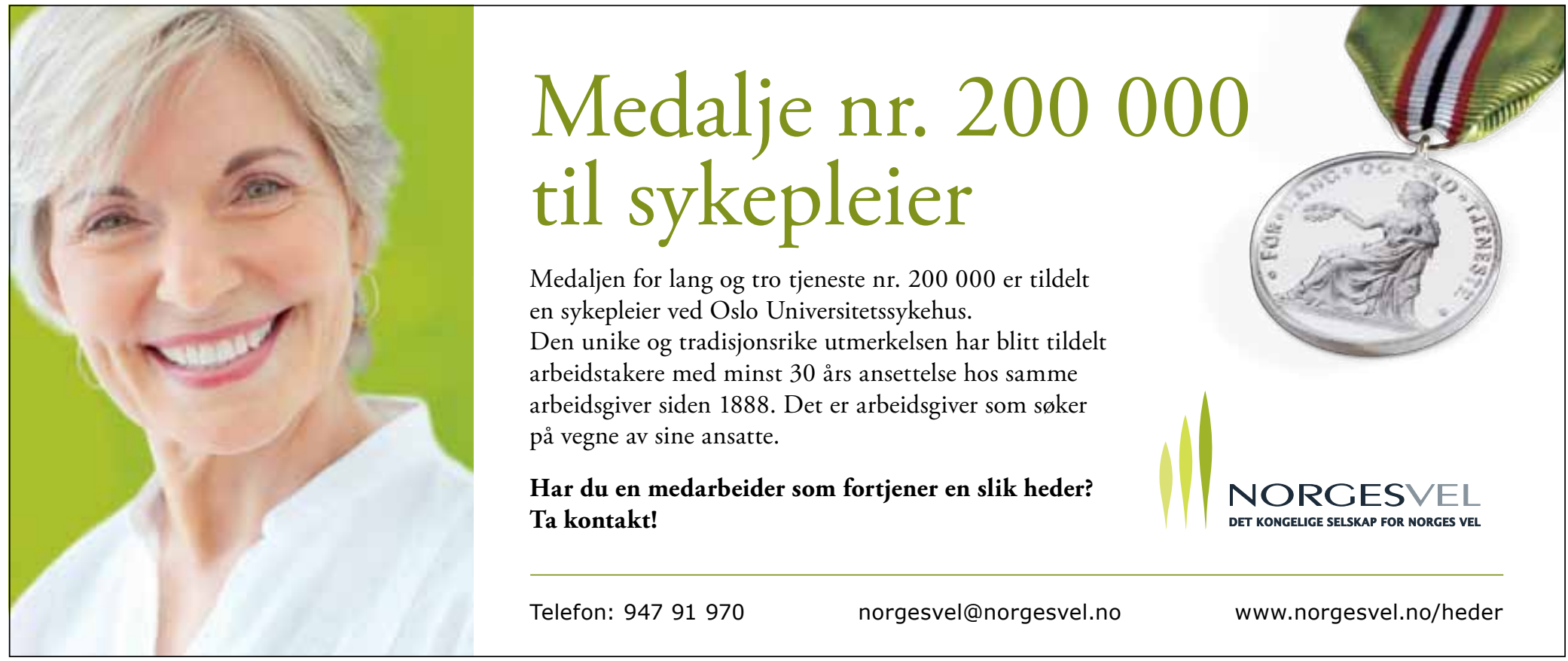

